\title{
Antitumoral Properties of a Pincer-Type Isonicotinohydrazone-Hg(II) Complex
}

\section{Burcu Saygıdeğer Demir ${ }^{1}$ (D), Aycan Sezan ${ }^{1}$ (D), Ezgi Derinoz' ${ }^{1}$, Eylem Nas $^{1}{ }^{\mathbb{D}}$, Mehmet Ozerten $^{1} \mathbb{D}^{D}$, Ghodrat Mahmoudi ${ }^{2}$, Yasemin Saygideger ${ }^{1,3}$}

\author{
${ }^{1} C$ ukurova University, Departmant of Biotechnology, Institute of Natural and Applied Sciences, Adana, Turkey \\ ¿University of Maragheh, Department of Chemistry, Faculty of Science, Maragheh, Iran \\ ${ }^{3}$ Cukurova University, Department of Pulmonary, Faculty of Medicine, Adana, Turkey
}

ORCID IDs of the authors: B.S.D. 0000-0001-5179-0522; A.S. 0000-0003-1506-7083; E.D. 0000-0002-1951-6862; E.N. 0000-0003-3799-9172; M.O. 0000-0003-4868-0212; G.M. 0000-0002-4846-5283;Y.S. 0000-0003-3293-373X

Please cite this article as: Saygideger Demir B, Sezan A, Derinoz E, Nas E, Ozerten M, Mahmoudi G, Saygideger Y. Antitumoral Properties of a Pincer-Type Isonicotinohydrazone-Hg(II) Complex. Eur J Biol 2021; 80(2): 129-137.

DOI: 10.26650/EurJBiol.2021.1010029

\section{ABSTRACT}

Objective: The aim of this study was to evaluate the antitumoral properties of the novel $\mathrm{Hg}(\mathrm{SCN})_{2}$ complex of a pincer-type isonicotinohyrazone ligand (PTIH).

Materials and Methods: Hydrazine ligands were prepared through a Schiff base condensation between the 2-Acetylpyridine and isonicotinoyl acid hydrazide. PTIH was synthetized by a branch tube method using $\mathrm{Hg}(\mathrm{SCN})_{2}$. In vitro cell killing activity, the induction of apoptosis, the influence on motility, and the effects on mRNA expression to a motility-related gene (E-cadherin) of PTIH were evaluated in A549, HepG2, HUH7 cancer cell lines, and BEAS2B non-cancer cell line.

Results: PTIH was found to be cytotoxic to cancer cells, compared to non-cancers, and induced apoptosis. Additionally, it suppressed cell migration in A549 cells, leading to an increase in the levels of E-cadherin mRNA expression, and decreased colony formation in HepG2 and HUH7 cells. Through UV titration studies, it was determined that PTIH showed albumin binding and interacted with DNA by electrostatically and/or groove binding.

Conclusion: PTIH exerted more cytotoxic effects in some cancer cells than in normal cells. This feature and other anticancer properties make it a promising agent.

Keywords: Antitumor, cytotoxicity, apoptosis, isonicotinohydrazone, $\mathrm{Hg}(\mathrm{II})$ complex, E-cadherin

\section{INTRODUCTION}

Hydrazones are called N-N-O donor Schiff bases pincer type ligands, which are derived by the one-pot condensation reaction of substituted hydrazides with aldehydes and ketones in high yields (1-2). In general, metal complexes including hydrazones, by adding new structural and electronic properties to the organic skeleton, can add different biological binding properties to the compound (3). The biological activity of these metal complexes is influenced by the oxidation level and the other features of the metal as well as the structure of the ligand (4-6).
Charming chemical behaviors (ability to chelate, structural flexibility, etc.) and biological activities such as antibacterial, antiproliferative, antimalarial, and antitumoral make hydrazone ligands remarkable for drug design (7-9). There are less anti-tumor studies with $\mathrm{Hg}$ complexes compared to other transition metal complexes. However, recently, the superior cytotoxic effects of $\mathrm{Hg}$ (II) compounds have been recognized and have been the subject of new drug studies (10-12). Thimerosal (Ethyl (2-mercaptobenzoato- (2 -) - O, S) mercurate (1-) sodium), known as an antibacterial and antifungal, has been used for a long time in vaccines, eye drops, 
and contact lens solutions. Now, it has been discovered to have anti-cancer properties. In a study conducted on the TPC-1 thyroid cancer cell line, its in vitro cytotoxic effect was proven, and it was seen as a potential chemotherapeutic agent (10). In another study, the $\mathrm{Hg}$ (II) complex was found to cause significantly higher mitochondrial damage and ROS-induced cell death in A549 and MCF-7 cells compared to cisplatin (12).

The chemotherapeutic drugs of metal complexes are effectively used clinically despite their widely recognized side effects and increasing reports of resistance to these drugs $(1,2)$. The discovery of new metal complexes is important in overcoming the potential side effects of existing anticancer agents and in developing more effective and targeted cancer drugs $(3,13,14)$.

Recent studies on hydrazone-based metal complexes have shown that the presence of a methyl substituent in the imine carbon atom has a remarkable effect on the cytotoxicity of the complexes (15-17). Therefore, in our study, we chose a hydrazone ligand methyl-substitution in the imine carbon atom and the $\mathrm{Hg}$ (II) complex of this ligand to further increase its anticancer activity.

\section{MATERIALS AND METHODS}

\section{Materials and Physical Techniques}

All reagents and solvents were commercially available and used without further purification. To evaluate anticancer activities, three different cancer cell lines were used, of which one was non-small cell lung carcinoma (A549) and the other two were hepatocellular carcinoma (HepG2, Huh7). The A549 cell line was provided by Gaziantep University, and the HepG2 and Huh7 cell lines were from IBG Izmir. All cells were maintained in RPMI 1640 (HyClone Cat. No: SH30027.01), supplemented with 10\% FBS (fetal bovine serum) (HyClone Cat. No: SV30160.03) and 1\% antibiotics (HyClone Cat. No: SV30079.01) in a $\mathrm{CO}_{2}$ incubator (Thermo Sci.) at $5 \% \mathrm{CO}_{2}$ and $21 \% \mathrm{O}_{2}$. Cells were harvested using Trypsin (HyClone Cat. No: SH30042.01), and a phosphate buffer solution (PBS) 1X (HyClone Cat. No: SH30256.01) was used to wash the plated cells or cell pellets when necessary. PTIH was dissolved in dimethyl sulphoxide (DMSO) with a $10 \mathrm{mM}$ stock concentration and was further diluted in the cell culture media during the experiments.

Hydrazine ligands were arranged through a Schiff base condensation between the 2-Acetylpyridine and isonicotinoyl acid hydrazide. These ligands were prepared as described previously (18).

Infrared spectra ( $\mathrm{KBr}$ pellets) were documented with a Perkin-Elmer spectrometer in the range of $400-4000 \mathrm{~cm}^{-1}$. Microanalyses were done through a Heraeus $\mathrm{CHN}-\mathrm{O}$-Rapid analyzer. Melting points are not corrected although they were measured on an Electrothermal 9100 instrument. HL: melting point (m.p). 240 C, Infrared (IR) $\left(\mathrm{cm}^{-1}\right)$ chosen bands: $3189(\mathrm{w}), 3073(\mathrm{w}), 1671$ $(\mathrm{s}), 1563(\mathrm{w}), 1382(\mathrm{~s}), 1302(\mathrm{~m}), 1216(\mathrm{~s}), 1144(\mathrm{~m})$, and 985(m), $836(\mathrm{~m}), 789(\mathrm{~m}), 735(\mathrm{~m}), 669(\mathrm{~m})$ and $566(\mathrm{~s})$.

\section{Synthesis of $\left[\mathrm{Hg}(\mathrm{SCN})_{2}(\mathrm{HL})\right](\mathrm{PTIH})$}

A simple formula (branched tube glass) was used to synthesize and purify PTIH, as explained before (19), and is summarized in Figure 1. In this way, organic ligand and the related metal salt were placed in the main arm of the branched tube. Ethanol was carefully added to fill the arms, the tube was sealed, and the ligand-containing arm was plunged in a bath containing oil heated to $60^{\circ} \mathrm{C}$ while the branched arm was kept at room temperature. After an appropriate time, crystals were retrieved from the cool arm and washed with acetone and ether after filtration and allowed to dry in the air.

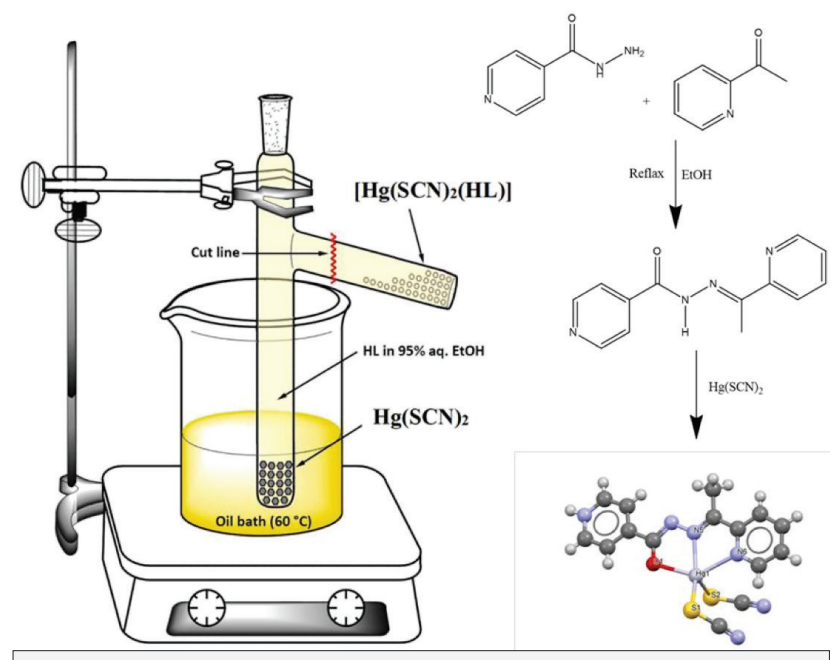

Figure 1. Graphical representation of the apparatus used in the syntheses of PTIH $\left(\left[\mathrm{Hg}(\mathrm{SCN})_{2}(\mathrm{HL})\right]\right)$, synthesis reaction and crystal structure of the PTIH.

Reactant materials: $\mathrm{HL}=2-$ Acetylpyridine isonicotinoyl hydrazone, mercury(II) thiocyanate.

Product: yellow-green, m.p. $180^{\circ} \mathrm{C}$.

Yield (based on $\left.\mathrm{Hg}(\mathrm{SCN})_{2}\right): 0.240 \mathrm{~g}$, (84\%). Anal. Calcd for $\mathrm{C}_{15} \mathrm{H}$ ${ }_{12} \mathrm{HgN}_{6} \mathrm{OS}_{2}$ : C, 32.34; H, 2.17; N, 15.09\%. Fund: C, 32.60; H, 2.22; N, $15.29 \%$.

IR $\left(\mathrm{cm}^{-1}\right)$ selected bands: 3368(w), $2993(\mathrm{w}), 2061(\mathrm{vs}), 1622(\mathrm{~m})$ $1593(\mathrm{~m}), 1534(\mathrm{~s}), 1481(\mathrm{~s}), 1438(\mathrm{~m}), 1288(\mathrm{~s}), 1157(\mathrm{~m}), 948(\mathrm{~m})$, $834(\mathrm{~m}), 787(\mathrm{~m})$ and $699(\mathrm{~m})$.

\section{Cytotoxicity Assay}

PTIH was dissolved in DMSO at $10 \mathrm{mM}$ concentration and tested for its cytotoxicity across four distinct cell lines (A549, HepG2, HUH7, and BEAS2B) using MTT (Thiazolyl Blue Tetrazolium Bromide) as described earlier (20). Briefly, the cells $\left(1.0 \times 10^{4} / 200\right.$ $\mathrm{mL} /$ well) were split into 96 -well plates and incubated overnight at $37^{\circ} \mathrm{C}, 5 \% \mathrm{CO}_{2}$, and $80 \%$ humidity in their respective medium (RPMI for A549 and, BEAS2B and DMEM for HUH7 and HEPG2, respectively) containing $10 \%$ FBS and $1 \%$ antibiotics. The media were replaced with increasing concentration of $\mathrm{PTIH}$, ranging between $0-100 \mu \mathrm{M}$ and containing even amounts of DMSO for $24 \mathrm{~h}$ at similar incubation conditions. MTT was added to the 
wells at $0.5 \mathrm{mg} / \mathrm{mL}$ final concentration before being maintained in the incubator for another $4 \mathrm{hrs}$. At the end of the incubation time, the supernatants were carefully removed, 50 $\mu \mathrm{L}$ DMSO was added to each well, and then, absorbance was measured at $570 \mathrm{~nm}$ and $630 \mathrm{~nm}$ (for background) in a microplate reader (Biochrom EZ Read 400). The way of calculating the percentage of living cells was done by using the equation (A) sample/ (A) control $\times 100$. In this process, the sample can be compared with control cells by ignoring PTIH.

\section{Flow Cytometric Apoptosis Detection Assay}

Biolegend apoptosis detection kit protocol was used to perform Annexin-V/PI staining and apoptotic cell detection (21) in A549, HepG2, and HUH7 cells. Cells $\left(1.0 \times 10^{5}\right.$ cells $\left./ \mathrm{mL}\right)$ were either treated with PTIH or DMSO (control) for $24 \mathrm{hrs}$ before harvesting, and the suspensions of the cells and harvested cells were collected and centrifuged. The pellets were washed with PBS two times. After incubation with the indicated dyes according to the kit's protocol, the fluorescence emission was detected at $633 \mathrm{~nm}$ in a flow cytometer (Beckman Coulter/CytoFLEX, United States).

\section{Cell Motility Assay}

A549 cells were plated in 6-well plates in a regular growth medium containing 10\% FBS. After $24 \mathrm{hrs}$ (when the cells were $100 \%$ confluent), a straight-line scratch was formed on cell layers with a sterile $200 \mu \mathrm{L}$ disposable pipette tip and washed with PBS. In turn, the cells were treated either with $I C_{50}$ concentration of the PTIH or with DMSO as a control. Images of cell migration were taken using an inverted microscope at times between 0 and $24 \mathrm{hrs}$ after the scratch. The percent closure ratio was measured using Image J software (NIH, USA, Version 1.53a).

\section{Colony Formation Assay}

A colony-forming efficiency assay was performed in 6 well plates. The cells were seeded at a quantity of 200 cells/well (for HepG2 and HUH 7) and of 300 cells/well (for A549) in a $3 \mathrm{~mL}$ complete culture medium. Two different concentrations of PTIH were applied to cells for 72 hours. Then, the old medium was removed, and a new fresh complete medium (not containing PTIH) was added to the cells. The medium was changed with the new one twice a week. After a total of three weeks, the colonies formed were dyed with a methylene blue solution (50\% Methanol, 50\% distilled water, and $0.4 \mathrm{~g}$ methylene blue) and were counted.

\section{Quantitative Polymerase Chain Reaction (qPCR)}

Cells, either treated with PTIH or an equal amount of DMSO for 4 hours, underwent RNA extraction using a commercially available RNA isolation kit (Macherey-Nagel) and reverse-transcribed (Thermo Fisher) according to the manufacturer's protocols. A quantitative PCR was performed in 3 replicates on a 96well plate using a SYBR Green qPCR Master Mix (Ampliqon). 18S rRNA was used as an internal control gene, and fold differences in the expression levels of the genes between the samples were calculated using the comparative Cycle threshold (CT) method, as previously described (20). 18S rRNA: sense: 5'-cttagagggacaagtggcg-3 ', non-sense: 5'-acgctgagccagtcagtgta-3 ';
E-cadherin: sense: 5'-acactgccaactggctggagatta-3 ', antisense: 5'-tgattagggctgtgtacgtgctgt-3 ' primer pairs were used.

\section{BSA Binding Assay}

BSA was used to examine the protein binding kinetic of the PTIH. Bovine serum albumin (BSA) was chosen for studying the drug interaction because of its structural similarity to human serum albumin (HSA) and for being easily available and inexpensive. $1 \mu \mathrm{M}$ BSA was dissolved in PBS (PH: 7.0), and the change in absorbance was monitored in a UV-visible spectrophotometer at 200-400 $\mathrm{nm}$ wavelength by increasing the concentration of PTIH (0-10 $\mu \mathrm{M})$ (UV titration) against the constant amount of BSA.

\section{DNA Binding Assay}

Experiments of PTIH binding with CT-DNA (Calf Thymus-DNA) were carried out within $1 \mathrm{mM}$ trizma hydrochloric acid (Tris- $\mathrm{HCl}$ ) with $1 \mathrm{mM}$ EDTA, pH 7.5 buffer solution. The CT-DNA solution in this buffer showed a UV absorption rate of about 2.5 at 260 and $280 \mathrm{~nm}$, which means that the DNA did not contain sufficient proteins, i.e., it was pure (22). The DNA concentration was identified by an absorption spectroscopy using a molar extinction coefficient value of $6600 \mathrm{dm}^{3} \mathrm{~mol}^{-1} \mathrm{~cm}^{-1}$ at $260 \mathrm{~nm}$. PTIH was dissolved in a solvent consisting of 5\% DMSO and 95\% pH 7.5 Tris buffer. With the constant concentration of PTIH $(25 \mu \mathrm{M})$, the DNA concentration was gradually increased (2.5-25 $\mu \mathrm{M})$, and absorption titration was performed. The study aim was to eliminate DNA self-absorption at wavelengths. Therefore, an equal amount of DNA was added to both the test solution and the reference solution. The $\mathrm{Kb}$ (intrinsic binding constant) value was calculated using the Wolfe-Shimmer equation (23) with the ab-

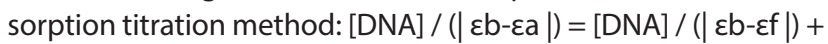
$1 /\{\mathrm{Kb}(|\varepsilon b-\varepsilon f|)\}$ where [DNA] is the DNA concentration in base pairs; $\varepsilon a, \varepsilon f$, and $\varepsilon b$ represent Aobsd/[PTIH], the extinction coefficient of the free complex (PTIH), and the extinction coefficient of PTIH in the fully DNA-bound form, respectively. The Kb value is described by the ratio of the slope to intercept in the graph [DNA] / (| عa - $\varepsilon f \mid)$ versus [DNA].

\section{Statistical Analysis}

Statistical analysis was shown with Prism V.8 Software. (GraphPad, USA). Non-linear regression analysis was performed for $\mathrm{IC}_{50}$ calculations, and Pearson's chi-square tests were used for the comparison of two different conditions or treatments. $p<0.05$ was considered significant.

\section{RESULTS}

We evaluated the cytotoxicity of the PTIH in 4 different cell lines by MTT test. Cells were treated with 8 different concentrations of PTIH containing equal amounts of DMSO in each well. After absorbance measurements, we calculated the $I C_{50}$ values of PTIH for A549, HepG2, and HUH7 cells, and the results were 24, 24 and $17 \mu \mathrm{M}$, respectively (Figure 2 ). We also evaluated the cytotoxicity of PTIH on BEAS2B, which is a non-cancerous bronchial epithelial cell line, and the $\mathrm{IC}_{50}$ value of PTIH was found to be higher $(87 \mu \mathrm{M})$ in these cells (Figure 2), which indicated that it might be less toxic to normal cells. 

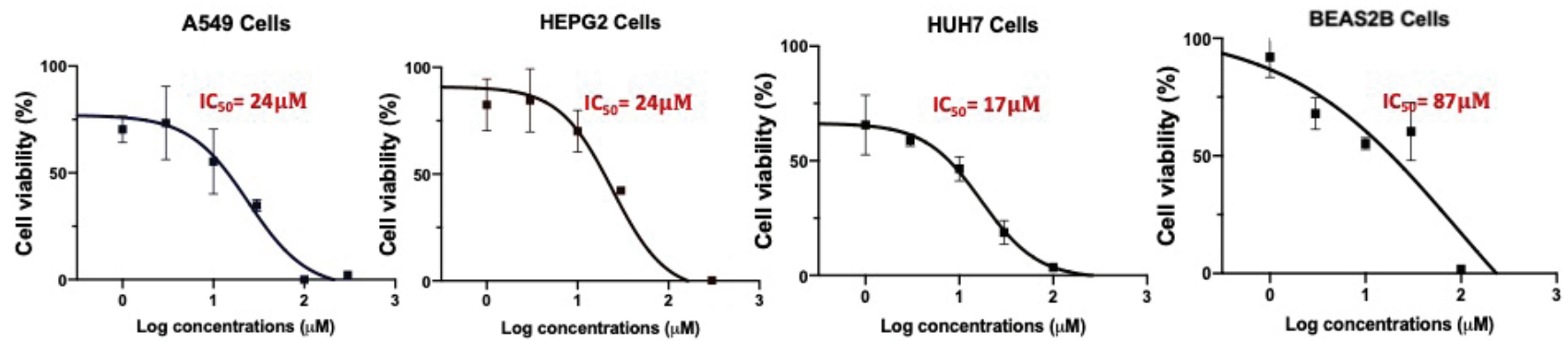

Figure 2. Cytotoxic effects of PTIH ( $\left.\left[\mathrm{Hg}(\mathrm{SCN})_{2}(\mathrm{HL})\right]\right)$ on cancer and non-cancer cells. MTT (Thiazolyl Blue Tetrazolium Bromide) test was performed to evaluate cytotoxicity with the increased concentrations of PTIH (0-0.3-1-3-10-30-100 and $300 \mu \mathrm{M})$ for $24 \mathrm{hrs}$. Graphs show the best curve fit of non-linear regression analysis of $24 \mathrm{~h} \mathrm{PTIH}$ treated A549, HepG2, HUH7, and BEAS2B cells respectively. Calculated $\mathrm{IC}_{50}$ values of the PTIH on these cell lines are also given above each curve.

After determining the cytotoxicity of PTIH, we tested the apoptotic effect of PTIH in cancer cells. We performed a flow cytometry experiment to detect apoptotic cells after 48-hour incubation with $50 \mu \mathrm{M} \mathrm{PTIH}$. The apoptotic cell ratio was calculated as
28.36\% in the A549 cells, $99.30 \%$ in HepG2 cells, and $61.82 \%$ in $\mathrm{HUH7}$ cells (Figure 3 ). There is a statistically significant difference between the apoptosis percentages of the control and the PTIH-treated cells.

\section{Control

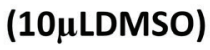
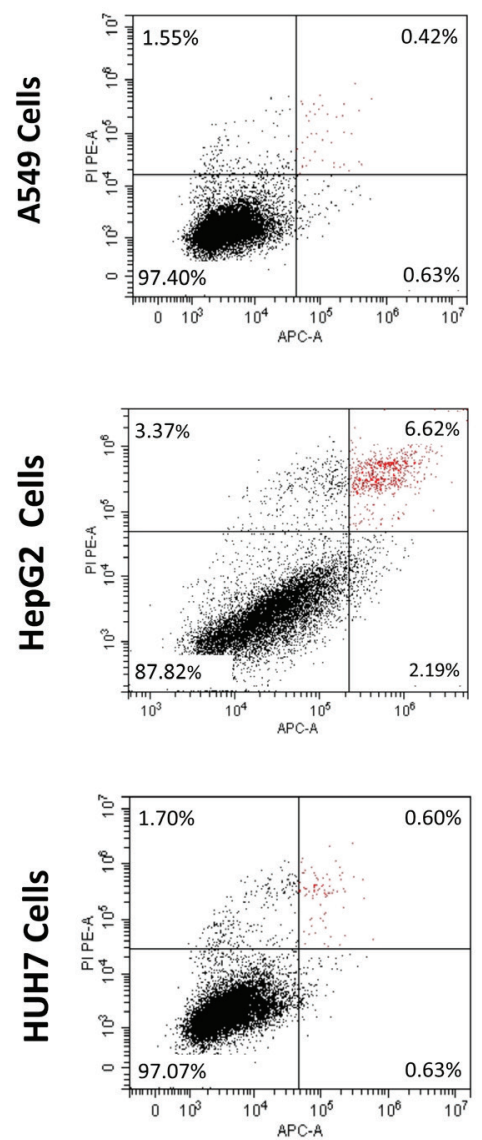

PTIH

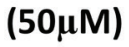
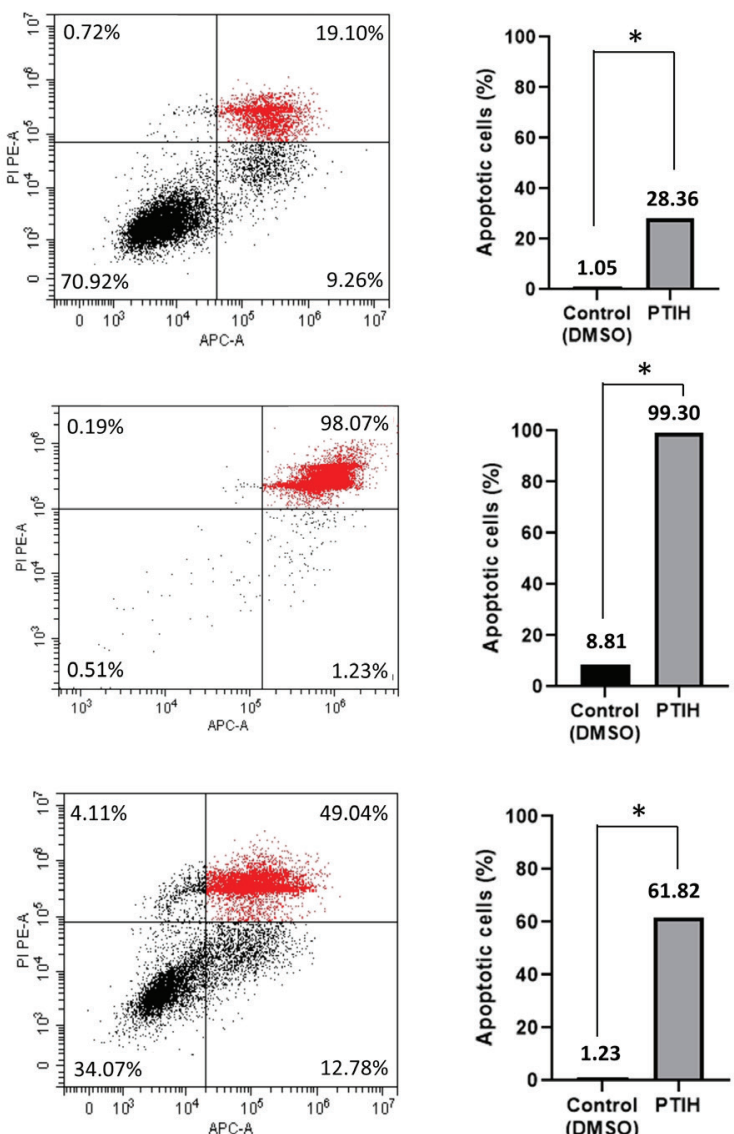

Figure 3. Apoptotic cell rates of A549, HepG2, and HUH7 cells treated with PTIH ([Hg(SCN) $\left.\left.)_{2}(\mathrm{HL})\right]\right)(50 \mu M)$ and equal amount of DMSO (Dimethyl Sulfoxide) as a control. Living and apoptotic cells were determined by flow cytometry. Both right quadrants (upper (late) and lower (early)) indicate the apoptotic cells of the population, while the left lower quadrant gives the percentage of viable cells. Percentages of entire (early and late) apoptotic cells in the A549, HepG2 and HUH7 cells are showed by bar diagrams (*p<0.05). 
In addition, we performed a motility assay and demonstrated that PTIH strongly suppressed the migration of A549 cells. While $75.50 \pm 1.26 \%$ of the wound was closed in the control plate, there was $4.40 \pm 0.80 \%$ closure in the PTIH treated plate at the end of the 24-hour treatment (Figures $4 \mathrm{a}-\mathrm{b}$ ). We also extracted RNA from the cells and ran a quantitative PCR analysis to detect E-cadherin mRNA level differences in DMSO and
PTIH treated cells (Figure 4c). E-cadherin expression of cells treated with PTIH increased 9-fold $(9.03 \pm 5.99)$ compared to the control.

We further assessed the effect of PTIH on the colony-forming ability of the cells, which the results showed that it significantly led to decreased colony formation in HepG2 and Huh7 cells in increasing concentrations (Figure 5). a

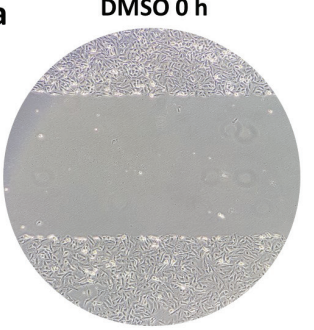

PTIH O h

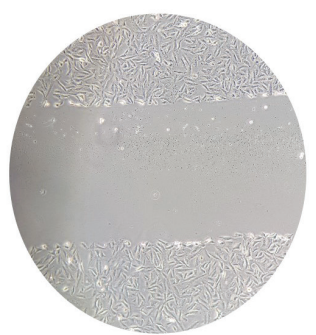

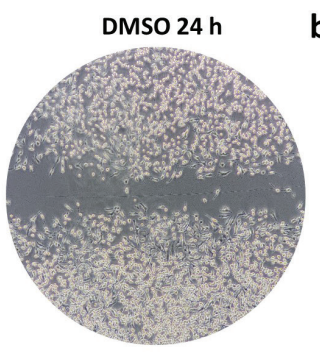

PTIH $24 \mathrm{~h}$

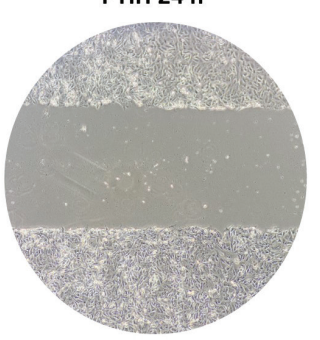

b

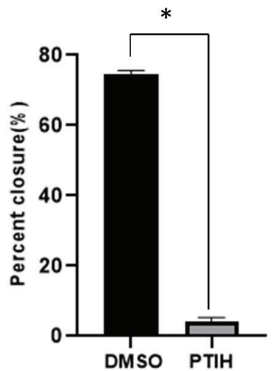

c

E-Cadherin mRNA expression

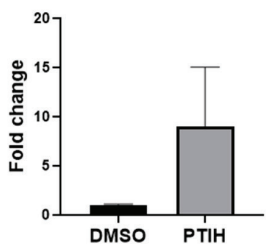

Figure 4. a: 0 and 24-hours representative images from the wound healing (motility) assay in the presence of DMSO, the solvent of PTIH $\left(\left[\mathrm{Hg}(\mathrm{SCN})_{2}(\mathrm{HL})\right]\right)$ and 50 micromolar PTIH $\left(\left[\mathrm{Hg}(\mathrm{SCN})_{2}(\mathrm{HL})\right]\right)$ as controls, b: shows percent wound closure bar graph $\left({ }^{*} \mathrm{p}<0.05\right), \mathbf{c}$ : shows a bar graph where gene expression of E-cadherin is normalized to $18 \mathrm{~S}$ rRNA and fold differences are calculated using the comparative CT method.

HEPG2

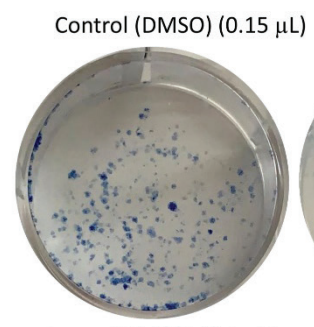

Control(DMSO) $(0.3 \mu \mathrm{L})$

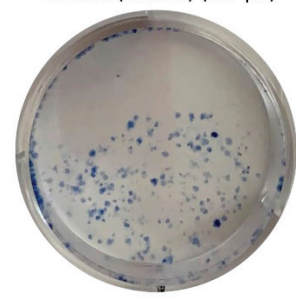

\section{HUH7}

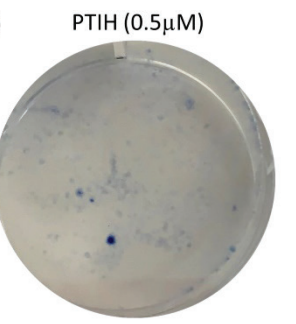

PTIH $(1 \mu \mathrm{M})$

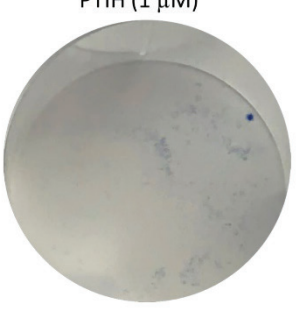

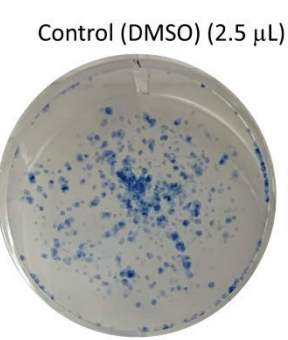

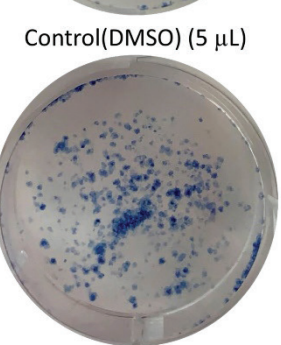

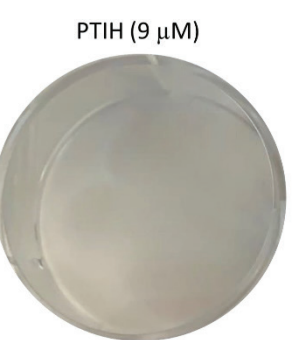

PTIH $(18 \mu \mathrm{M})$

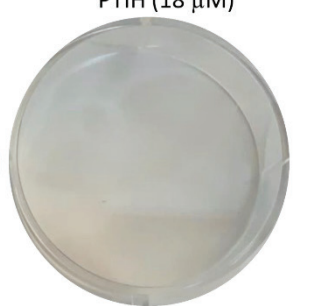

Figure 5. Colony formation assay was performed in HepG2 and HUH7 cells. Cells exposed to PTIH ([Hg(SCN) 2 (HL)]) at two different concentrations. The results were compared to the negative control (DMSO) (Dimethyl Sulfoxide). Cells were allowed to grow for 10-14 days before staining with methylene blue solution to visualize colonies. 
The addition of PTIH causes the intensity of pure BSA to increase in the absorption band at $280 \mathrm{~nm}$ and also the blue shift of about $5 \mathrm{~nm}$ at $1 \mu \mathrm{M}$ BSA with $10 \mu \mathrm{M} \mathrm{PTIH}$ (Figure 6). This result shows that PTIH changes the polarity of the microenvironment around the Trp and Tyr amino acids of BSA. The change in the absorption band of BSA in the presence of PTIH indicates that the PTIH-BSA interaction is in the form of static quenching (24-26).

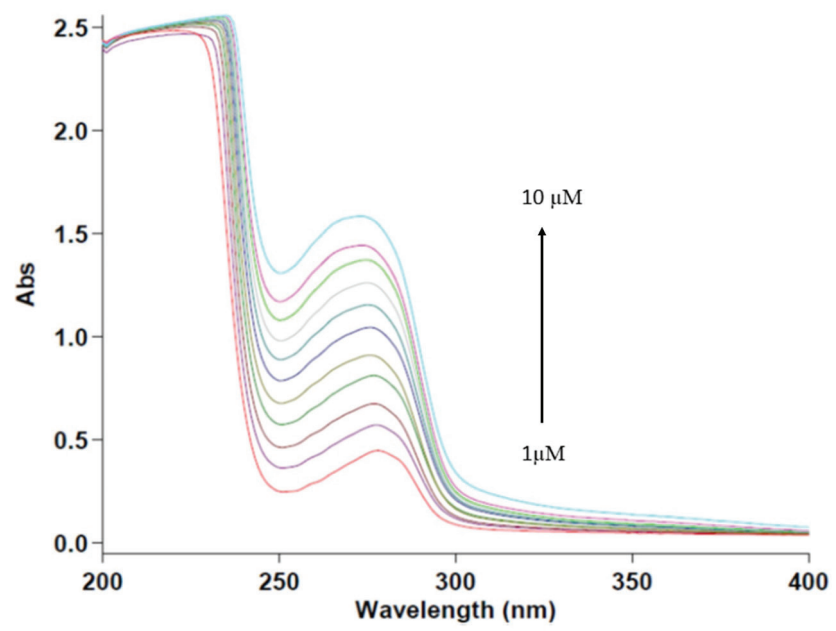

Figure 6. Absorption spectra of BSA (Bovine serum albumin) $(1 \mu \mathrm{M})$ and with PTIH $\left(\left[\mathrm{Hg}(\mathrm{SCN})_{2}(\mathrm{HL})\right]\right)(0-10 \mu \mathrm{M})$.

The UV absorption spectrum of PTIH as a result of increasing CT- DNA concentrations are shown in Figure 7. In the absence of DNA, PTIH exhibited maximum absorbance at $289 \mathrm{~nm}$ can be assigned to the $\pi-\pi^{*}$ transition. The hyperchromic effect was observed upon the addition of CT-DNA. Additionally, small blueshifts have been accompanied by the increase in peaks. This indicates an interaction between PTIH and CT-DNA (Kb $\left.8.35 \times 10^{5} \mathrm{~L} \mathrm{~mol}^{-1}\right)$.

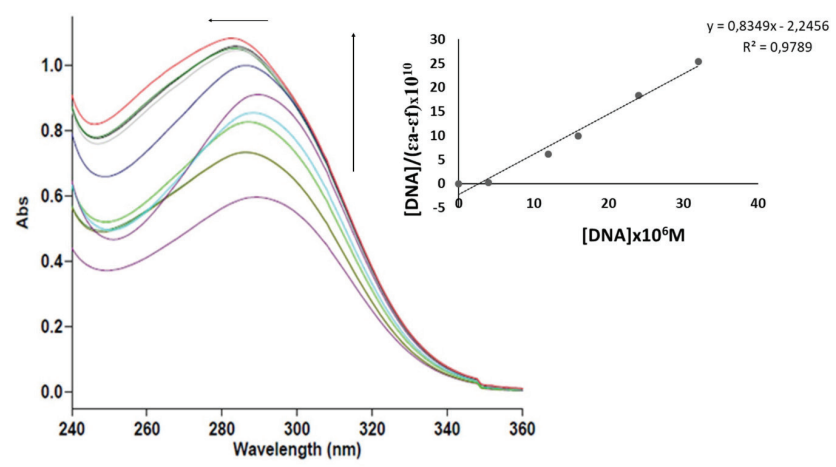

Figure 7. Absorption spectra of $\mathrm{PTIH}\left(\left[\mathrm{Hg}(\mathrm{SCN})_{2}(\mathrm{HL})\right]\right)(80 \mu \mathrm{M})$ in the presence of increasing amounts of CT-DNA (Calf ThymusDNA) (in the range of $0-40 \mu \mathrm{M}$ ). Arrows show the absorbance changes upon increasing DNA concentration. (E) Plots of [DNA]/ $(\varepsilon a-\varepsilon f)$ versus $[D N A]$ for the PTIH $\left(\left[\mathrm{Hg}(\mathrm{SCN})_{2}(\mathrm{HL})\right]\right)$ with CT-DNA $\left(\mathrm{Kb}=8.35 \times 10^{5} \mathrm{M}^{-1}\right)$.

\section{DISCUSSION}

According to the cytotoxicity results, PTIH was more effective than cisplatin in $\mathrm{HUH7}$ cells compared to previous reports in the literature $\left(\mathrm{IC}_{50}=58.77 \mu \mathrm{M}(27)\right.$ and $\left.20.5 \mu \mathrm{M}(28)\right)$ in the means of cell killing activity. The efficiency of PTIH in HepG2 cells was also substantially good compared to previous studies on some hydrazone metal complexes $(15,29)$. PTIH showed good cytotoxic activity in the A549 cell when compared to the effects of some similar hydrazone metal complexes in A549 cells (30, 31). In HUH7 cells, PTIH also showed good anticancer activity compared to some similar molecules in the literature $(32,33)$. In this study, we have not performed flow cytometric analyses on BEAS2B cells, which may be counted as a limitation, but the fact that the $\mathrm{IC}_{50}$ value of PTIH is higher in BEAS2B cells than in cancer cells indicate that PTIH will specifically kill cancer cells at low doses if it is used as a drug.

The biological activity of a metal complex is determined as much as the metal itself, the number of valence electrons, the conformational and electronic nature of the organic ligand it is in, and other groups attached to that ligand. The HL ligand has a flexible conformational structure and multiple hydrogen bonding sites. Aromatic rings at either end of the HL gain the ability to form $\pi \ldots \pi$ stacking interactions into the structure (34).

The anticancer activity mechanisms of $\mathrm{Hg}$ (II) complexes were not studied until 2016 (35). According to an in silico docking study with a $\mathrm{Hg}$ (II) complex, the binding energy to the epidermal growth factor receptor (EGFR protein) was calculated as $-5.79 \mathrm{kcal} / \mathrm{mol}$, and it was theoretically claimed that apoptosis could be induced with the complex in cells with EGFR mutations (11). In a recent study, it has been shown by docking studies that a $\mathrm{Hg}(\mathrm{II})$ complex binds to DNA, and it has been experimentally shown that it displays nuclease activity. Besides this, the same study claimed that $\mathrm{Hg}$ (II) activated G0/G1 cell arrest and apoptotic cell death in cancer cells (12). The thiocyanate groups (SCN) in its structure give some properties to PTIH. It is known that thiocyanates cause DNA damage by creating oxidative stress (36), and it has been reported that they inhibit some enzymes whose expression is increased in cancer due to the potential of binding to the cysteine amino acids of the sulfur atom in their structure $(36,37)$. In a study comparing different groups attached to the same metal complex, it was revealed that the SCN group had a better cytotoxic effect than the compounds containing other side groups (38).

In addition to cytotoxic activity, PTIH showed apoptosis induction as well as suppressed cell migration in cancer cells. In the repeated experiments, we obtained similar results that while apoptotic cell rate was lower in A549 cells, it showed very high apoptotic activity in HepG2 and HUH7 cells, which indicate that a possible active pathway was affected in hepatocellular carcinoma cells or a resistance mechanism might be in charge in A549 lung cancer cells. Different apoptotic activities of $\mathrm{Hg}$ (II) or hydrazone-based compounds in different cell lines are also encountered in the literature $(12,15)$. Which molecules in the 
apoptotic pathway the drug candidate targets may be a new area of research. The deficiency of E-cadherin-induced cell-cell adhesion in tumor cells and its transformation from epithelial to mesenchymal characteristics and gaining invasive properties are the core of the metastasis pathways in most solid tumors (39). Therefore, we performed a motility assay and demonstrated that PTIH statistically significantly and strongly suppressed the migration of A549 cells. As a result, PTIH increased 9-fold $(9.03 \pm 5.99)$ the expression of E-cadherin compared to DMSO in the $\mathrm{A} 549$ cell supporting motility assay results.

It is very important to examine the interaction mechanism of serum albumin, the most abundant protein in plasma, and drug candidates because the interactions of drugs with serum albumin may cause them to lose their biological properties or gain better biological activity while being transported in the body. BSA, which is similar to human serum albumin, is widely used in such drug studies. BSA binding studies are performed by the spectrophotometric titration method (UV-visible absorption). The absorption of BSA at $280 \mathrm{~nm}$ is monitored. The changes in the structure of aromatic amino acids tyrosine (Tyr), tryptophan (Trp), and phenylalanine (Phe) asa result of binding are reflected in the spectrum. Whether potent drugs bind statically or dynamically to BSA is determined by comparing the characteristic absorption spectra of pure BSA and BSA-drug solutions. Since the dynamic coupling only affects the excited state of the fluorophore group, no change is observed in the absorption spectra. Static bonding, on the other hand, causes a change in the absorption spectrum of the fluorophore group with the formation of PTIH with BSA (24-26).

The most common method used to examine the binding potential of metal complexes with DNA is electronic absorption titration $(40,41)$. If there is an interaction between the metal complexes and DNA, changes occur in the spectrum transitions of the complex. As a result of intercalative interactions between DNA and small molecules, hypochromism and redshift are usually observed in the spectrum (42). If DNA and small molecules perform groove bonding or electrostatic attraction between them, a hyperchromic effect showing conformational changes in the structure is observed, and a slight redshift can be observed. The hyperchromic effect and blueshift observed in the figure indicate that PTIH interacts with CT-DNA via groove binding and/or electrostatic attraction (42-45). Kb value of PTIH indicates that it has a good binding affinity with DNA in comparison with the $\mathrm{Kb}$ value for classical intercalator ethidium bromide $\left(\mathrm{Kb}=1.4 \times 10^{5} \mathrm{M}^{-1}\right)(46)$ and resembles studies in the literature $(47,48)$.

One of the limitations of this study is that we did not perform any experiment to analyze the possible molecular alterations of the compound in cell culture conditions, which may need further evaluation in future studies.

\section{CONCLUSION}

According to in vitro experiments on A549, HepG2, and HUH7 lung cancer cells, PTIH has been found to exert dose-depen- dent cytotoxic effects in cell lines. It has also been shown to induce apoptotic cell death. It was less cytotoxic to BEAS2B, a non-cancerous lung epithelial cell line. It was also determined by PCR analysis that it induces E-cadherin expression in A549 cells, indicating prevention of metastasis that was confirmed by cell motility assay. Moreover, PTIH has been proven to effectively stop colony generation in cancer cells. PTIH performed its antitumoral activity by interacting with DNA in grooves and/or electrostatically. Therefore, it may be a promising anti-tumor agent.

Acknowledgements: We thank Gaziantep University and Izmir Biomedicine and Genome Center (IBG) for providing the cell lines. We are also greatful to Çukurova University genetic diseases diagnosis and treatment center (AGENTEM) for device usage support.

Informed Consent: Written consent was obtained from the participants.

Peer Review: Externally peer-reviewed.

Author Contributions: Conception/Design of Study- B.S.D., Y.S.; Data Acquisition- B.S.D., A.S., E.D., E.N., M.O., G.M., Y.S.; Data Analysis/Interpretation- B.S.D., A.S., E.D., G.M., Y.S.; Drafting Manuscript- B.S.D., Y.S.; Critical Revision of Manuscript- Y.S.; Final Approval and Accountability- B.S.D., A.S., E.D., E.N., M.O., G.M., Y.S.

Conflict of Interest: Authors declared no conflict of interest.

Financial Disclosure: Authors declared no financial support.

\section{REFERENCES}

1. Szabó KJ, Wendt OF. Pincer and pincer type complexes, applications in synthesis and catalysis: Wiley-VCH, Weinheim, Germany, 2014.

2. Mahmoudi G, Bauzá A, Gurbanov AV, Zubkov Fl, Maniukiewicz W, Rodríguez-Diéguez A, et al. The role of unconventional stacking interactions in the supramolecular assemblies of $\mathrm{Hg}$ (II) coordination compounds. CrystEngComm 2016; 18: 9056-66.

3. Mahmoudi G, Zareba JK, Bauzá A, Kubicki M, Bartyzel A, Keramidas $A$, et al. Recurrent supramolecular motifs in discrete complexes and coordination polymers based on mercury halides: prevalence of chelate ring stacking and substituent effects. CrystEngComm 2018; 20: 1065-76.

4. Blake AJ, Champness NR, Hubberstey P, Li WS, Withersby MA, Schröder M. Two- and three-dimensional CuSCN co-ordination networks including new CuSCN structural motifs. Coord Chem Rev 1999; 183: 117-38.

5. Sarkar M, Biradha K. Crystal engineering of metal-organic frameworks containing amide functionalities: Studies on network recognition, transformations, and exchange dynamics of guests and anions. Cryst Growth Des 2007; 7: 1318-31.

6. Beheshti A, Clegg W. Nobakht V, Harrington RW. Metal-to-ligand ratio as a design factor in the one-pot synthesis of coordination polymers with $\left[\mathrm{MS}_{4} \mathrm{Cu}_{\mathrm{n}}\right](\mathrm{M}=\mathrm{W}$ or $\mathrm{Mo}, \mathrm{n}=3$ or 5$)$ cluster nodes and a flexible pyrazole-based bridging ligand. Cryst Growth Des 2013; 13: 1023-32.

7. Angelusiu MV, Barbuceanu SF, Draghici C, Almajan GL. New Cu(II), $\mathrm{Co}(\mathrm{II}), \mathrm{Ni}(\mathrm{II})$ complexes with aroyl-hydrazone based ligand. Synthesis, spectroscopic characterization, and in vitro antibacterial evaluation. Eur J Med Chem 2010; 45: 2055-62. 
8. Aslan HG, Ozcan S, Karacan N. Synthesis, characterization and antimicrobial activity of salicylaldehyde benzenesulfonylhydrazone (Hsalbsmh) and its Nickel(II), Palladium(II), Platinum(II), Copper(II), Cobalt(II) complexes. Inorg Chem Commun 2011; 14: 1550-53.

9. Xu Z, Zhang X, Zhang W, Gao Y, Zeng Z. Synthesis characterization DNA interaction and antibacterial activities of two tetranuclear cobalt(II) and nickel(II) complexes with salicylaldehyde 2-phenylquinoline-4-carboylhydrazone. Inorg Chem Commun 2011; 14: 1569-73.

10. Zhang L, He M, Zhang $Y$, Nilubol N, Shen M, Kebebew E. Quantitative high-throughput drug screening identifies novel classes of drugs with anticancer activity in thyroid cancer cells: opportunities for repurposing. J Clin Endocrinol Metab 2012; 97(3): E319-28.

11. Malella R, Konkanchi R, Guda R, Munirathinam N, Gandamalla D, Yellu NR, et al. Zn(II), Cd(II), and Hg(II) metal complexes of 2-aminonicotinaldehyde: Synthesis, crystal structure, biological evaluation, and molecular docking study. Inorganica Chim. Acta 2017; 469: 66-75.

12. Icsel C, Yilmaz VT, Aydinlik S, Aygün M. Zn(II), Cd(II) and Hg(II) saccharinate complexes with 2,6-bis(2- benzimidazolyl)pyridine as promising anticancer agents in breast and lung cancer cell lines via ROS-induced apoptosis. Dalton Trans 2020; 49: 7842-51.

13. Yumnan S, Rajkumari L. Thermodynamics of the complexation of $\mathrm{N}$-(Pyridin-2-ylmethylene) isonicotinohydrazide with lighter lanthanides. J Chem Eng Data 2009; 54: 28-34.

14. Wolff SK, Grimwood DJ, McKinnon JJ, Turner MJ, Jayatilaka D, Spackman MA. Visualization and characterization of voids in crystalline materials. Dalton Trans 2011; 13: 1804-13.

15. Megger DA, Rosowski K, Radunsky C, Kösters J, Siteka B, Müller J. Structurally related hydrazone-based metal complexes with different antitumor activites variably induce apoptotic cell death. Dalton Trans 2017; 46: 4759-67.

16. Pape VFS, Türk D, Szabo P, Wiese M, Enyedy EA. Cook G, Synthesis and characterization of the anticancer and metal-binding properties of novel pyrimidinylhydrazone derivatives. Inorg Biochem 2015; 144: 18-30.

17. Pape VFS, Torh S, Füredi A, Szebenyi K, Lovrics A, Szabo P, et al. Design, synthesis and biological evaluation of thiosemicarbazones, hydrazinobenzothiazoles and arylhydrazones as anticancer agents with a potential to overcome multidrug resistance. Eur J Med Chem 2016; 117: 335-54.

18. Afkhami FA, Mahmoudi G, Qu F, Gupta A, Zangrando E, Fronteral A. Supramolecular architecture constructed from the hemidirected lead(II) complex with $\mathrm{N}^{\prime}$-(4-hydroxybenzylidene)isonicotinohydrazide. Inorganica Chim. Acta 2020; 502: 119350.

19. Mahmoudi G, Khandar AA, Afkhami AF, Miroslaw B, Gurbanov VA, Zubkov $F$, et al. Modulation of coordination in pincer-type isonicotinohydrazone Schiff base ligands by proton transfer. CrystEngComm 2019; 21: 108-17.

20. Saygideger Y, Saygıdeğer Demir B, Taskin Tok, Avci A, Sezan A, Baydar $O$, et al. Antitumoral effects of Santolina chameacyparissus on non-small cell lung cancer cells. J Exp Clin Med 2021; 38(3): 294-300.

21. https://www.biolegend.com/nl-be/products/apc-annexin-vapoptosis-detection-kit-with-pi-9788.

22. Marmur J, Doty P. Determination of the base composition of deoxyribonucleic acid from its thermal denaturation temperature. J Mol Biol 1983; 5: 109-18.

23. Wolfe A, Shimer GH, Meehan T. Polycyclic aromatic hydrocarbons physically intercalate into duplex regions of denatured DNA. Biochemistry 1987; 26: 6392-96.

24. Raja DS, Bhuvanesh NSP, Natarajan K. Biological evaluation of a novel water- soluble sulfur bridged binuclear copper (II) thiosemicarbazone complex. Eur J Med Chem 2011; 46: 4584-94. (b)
25. Raja DS, Paramaguru G, Bhuvanesh NSP, Reibensipes JH, Reanganathan R, Natarajan K. Effect of terminal N-substitution in 2-oxo-1, 2-dihydroquinoline-3-carbaldehyde thiosemicarbazones on the mode of coordination, structure, interaction with protein, radical scavenging, and cytotoxic activity of copper(II) complexes. Dalton Trans 2011; 40: 4548-59. (a)

26. Gupta RK, Sharma G, Pandey R, Kumar A, Koch B, Li P-Z, et al. DNA/ Protein binding, molecular docking, and in vitro anticancer activity of some thioether-dipyrrinato complexes. Inorg Chem 2013; 52 : 13984-96.

27. Brito AF, Abrantes AM, Pinto-Costa C, Gomes AR, Mamede AC, Casalta-Lopes J, et al. Hepatocellular carcinoma and chemotherapy: the role of p53. Chemotherapy 2012; 58: 381-86.

28. Ye R-R, Peng W, Chen B-C, Jiang N, Chen X-Q, Mao Z-W, et al. Mitochondria-targeted artesunate conjugated cyclometalated iridium(III) complexes as potent anti-HepG2 hepatocellular carcinoma agents. Metallomics 2020; 12: 1131-41.

29. Machakanur SS, Patil BR, Badiger DS, Bakale RP, Gudasi KB, Bligh SWA. Synthesis characterization and anticancer evaluation of novel tri-arm star shaped 1, 3, 5-triazine hydrazones. J Mole Struct 2012; 1011: 121-27.

30. Dasgupta S, Karim S, Banerjee S, Saha M, Saha KD, Das D. Designing of novel zinc (II) Schiff base complexes having acyl hydrazone linkage: Study of phosphatates and anti-cancer activity. Dalton Trans 2020; 49: 1232-40.

31. Wang F, Yin H, Cui J, Zhang Y, Geng H, Hong M. DNA-binding and BSA interaction of diorganotin (IV) complexes derived from hydrazone Schiff base. J Organomet Chem 2014; 759: 83-91.

32. Balaji S, Subarkhan MKM, Ramesh R, Wang H, Semeril D. Synthesis and structure of arene Ru (II) $\mathrm{N} \wedge \mathrm{O}$ chelating complexes: In vitro cytotoxicity and cancer cell death mechanism. Organometallics, 2020; 39 (8): 1366-75.

33. Li Z-H, Yang D-X, Geng PF, Zhang J, Wei HM, Hu B, et al. Design, synthesis and biological evaluation of $[1,2,3]$ triazolo[4,5-d] pyrimidine derivatives possessing a hydrazone moiety as antiproliferative agents. Eur J Med Chem 2016; 124: 967-80.

34. Saygıdeger Demir B, Mahmoudi G, Sezan A, Derinoz E, Nas E, Saygideger $Y$, et al. Evaluation of the antitumor activity of a series of the pincer-type metallocomplexes produced from isonicotinohydrazide derivative. J Inorg Biochem 2021; 223: 111525.

35. Marloye M, Berger G, Gelbcke M, Dufrasne F. A survey of the mechanisms of action anticancer transition metal complexes. Future Med Chem 2016; 8 (18): 2263-86.

36. Hać A, Brokowska J, Rintz E, Bartkowski M, Węgrzyn G, Antosiewicz $\mathrm{AH}$. Mechanism of selective anticancer activity of isothiocyanates relies on diferences in DNA damage repair between cancer and healthy cells. Eur J Nutr 2020; 59: 1421-32.

37. Lin RK, Zhou N, Lyu YL, Tsai YC, Lu CH, Kerrigan J, et al. Dietary isothiocyanate induced apoptosis via thiol modifcation of DNA topoisomerase Ilalpha. J Biol Chem 2011; 286: 33591-600.

38. El-bendary MM, Arshad MN, Asiri AM. Structure characterization and antitumor activity of palladium pseudo halide complexes with 4-acetylpyridine. J Coord Chem 2019; 72(18): 3088-101.

39. Ribatti D, Tamma R, Annese T, Epithelial-mesenchymal transition in cancer: A historical overview. Transl Oncol 2020; 13(6): 100773.

40. Kelly JM, Tossi AB, McConnell DJ, Uigin CO. A study of the interactions of some polypyridylruthenium(II) complexes with DNA using fluorescence spectroscopy, topoisomerisation, and thermal denaturation. Nucl Acids Res 1985; 13: 6017-34. 
41. Abdel-Rahman LH, El-Khatib RM, Nassr LA, Abu-Dief AM, Ismael M, Seleem AA. Metal based pharmacologically active agents: synthesis, structural characterization, molecular modeling, CT-DNA binding studies and in vitro antimicrobial screening of iron(II) bromosalicylidene amino acid chelates. Spectrochim Acta A Mol Biomol Spectrosc 2014; 117: 366-78.

42. Rahban M, Divsalar A, Saboury AA, Golestani A. Nanotoxicity and spectroscopy studies of silver nanoparticle: calf thymus DNA and K562 as targets. J Phys Chem 2010; 114: 5798-803.

43. Sarwar T, Husain MA, Rehman SU, Ishqi, HM, Tabish M. Multi-spectroscopic and molecular modeling studies on the interaction of esculetin with calf thymus DNA. Mol Biosyst 2015; 11(2): 522-31.

44. Liu R, Yan H, Jiang J, Li J, Liang X, Yang D, et al. Synthesis, characterization, photoluminescence, molecular docking and bioactivity of Zinc (II) compounds based on different substituents. Molecules, 2020; 25(15): 3459.
45. Draksharap A, Boersma AJ, Leising M, Meetsma A, Browne WR, Roelfes G. Binding of copper(II) polypyridyl complexes to DNA and consequences for DNA-based asymmetric catalysis. Dalton Trans 2015; 44: 3647-55.

46. Li W, Ji YY, Wang JW, Zhu YM. Cytotoxic activities and DNA binding properties of 1-methyl-7H-indeno[1,2-b] quinolinium-7-(4-dimethylamino) benzylidene triflate. DNA Cell Biol 2012; 31(6): 1046-53.

47. Franich AA, Živković MD, Milovanović J, Arsenijević D, Arsenijević $A$, Milovanović $M$, et al. In vitro cytotoxic activities, DNA- and BSA-binding studies of dinuclear palladium(II) complexes with different pyridine-based bridging ligands. J Inorg Biochem 2020; 210 : 111-58.

48. Li Y, Li Y, Wang N, Lin D, Liu X, Yang Y. Et al. Synthesis, DNA/BSA binding studies and in vitro biological assay of nickel(II) complexes incorporating tridentate aroylhydrazone and triphenylphosphine ligands. J Biomol Struct Dyn 2019; 38(17): 4977-96. 